\title{
DIPLOMASI KIAI NAHDLATUL 'ULAMA (NU) MELALUI KONFERENSI ULAMA INTERNASIONAL
}

\author{
Andi Purwono \\ Program Studi Ilmu Hubungan Internasional \\ Fakultas Ilmu Sosial dan Ilmu Politik \\ Universitas Wahid Hasyim. \\ Email : andipurwono75@gmail.com
}

\begin{abstract}
As the largest religious organization, Nahdlatul Ulama has had an international role since its inception. One of these roles is realized through the holding of several international conferences. This article aims to explain the reasons of these conferences and to describe the activities and contributions to the world and especially towards Indonesian foreign policy. This qualitative research used documentary/ literature study in collecting data. The research found that ideational motivation related to the logic of appropriateness (the call) to spread the teachings of Islam rahmatan lil alamin was the reason for the establishment. The conferences gave positive contribution as religious epistemic community, in building network, and in the framework of Islamic and western relations. Towards Indonesian foreign policy, these conferences, firstly emphasized the washathiyah / moderate character of Indonesian Islam which has proven to be compatible with democracy and modernity. Secondly, the thoughts and recommendations generated are valuable inputs for policy makers. Thirdly, the ulama network also has sharpen Indonesia's diplomacy in area Indonesia foreign policy implementation.
\end{abstract}

Key Words: Diplomacy, Conference, Ideational Motivation, Cononstructivism, Contributioni.

\section{A. PENDAHULUAN}

Sebagai organisasi keagamaan terbesar di dunia, Nahdlatul Ulama (NU) memiliki watak global sejak pendiriannya. Sejak berdiri pada tahun 1926, Perjalanan KH.Wahab Chasbullah dalam rangka Komite Hijaz yang memperjuangkan kebebasan bermazhab yang dianut oleh umat Islam dari berbagai belahan dunia menunjukkan pandangan global NU. Komite Hijaz adalah nama sebuah kepanitiaan kecil yang diketuai oleh KH Abdul Wahab Chasbullah dan bertugas menemui raja Ibnu Saud di Hijaz (Saudi Arabia) 
untuk melakukan diplomasi. Dengan demikian sebagaimana ditunjukkan dengan keberadaan Komite Hijaz, sejak awal NU berupaya memberikan respon terhadap perkembangan dunia internasional, dan ini menjadi faktor terpenting didirikannya organisasi NU.

Di era KH Abdurrahman Wahid (Gus Dur) dan kemudian KH. Hasyim Muzadi, kiprah internasional NU semakin kuat. Kiai Hasyim bahkan berupaya membuka diri untuk berkontribusi pada persoalan dunia internasional, seperti penanggulangan terorisme, resolusi konflik, isu radikalisme, isu lingkungan, dan perdamaian dunia. ${ }^{1}$ Para kiai NU memperluas jaringan internasional dengan membuka Pengurus Cabang Istimewa (PCI) NU di sejumlah negara baik eropa, Amerika, Asia, dan Timur Tengah serta menyelenggarakan diplomasi internasional forum konferensi internasional seperti ICIS, World Sufi Forum, dan ISOMIL.. Mengapa Nahdlatul Ulama menyelenggarakan diplomasi melalui beberapa forum konferensi internasional dan apa kontribusinya bagi dunia dan Indonesia?

Studi terdahulu tentang diplomasi sering memaknai diplomasi sebagai proses komunikasi yang diatur. ${ }^{2}$ Meski semula hanya menjadi aktivitas para pejabat resmi negara, diplomasi kini juga dilakukan oleh aktor bukan negara. Hal ini sejalan dengan kebutuhan komunikasi antar entitas di dunia.

Pandangan ini sejalan dengan pemahaman Hamilton dan Langhorne yang melihat aktor diplomasi bukan hanya negara namun entitas politik. ${ }^{3}$ Bahkan James der Derian menekankan aspek keterasingan dengan mendefinisikan diplomasi sebagai mediasi antara individu- individu,

\footnotetext{
${ }^{1}$ Nafiysul Qodar, Kisah KH. Hasyim Muzadi anak tukang roti yang Go Internasional, http://news.liputan6.com/read/2929927/kisah-kh-hasyim-muzadi-anak-tukang-roti-yang-gointernasional, di unduh pada tanggal 14 juni 2017, pukul 20.54 WIB.

${ }^{2}$ Costas M.Costantinou, On the Way to Diplomacy (Minneapolis University of Minesota Press, 1996), h. 25.

${ }^{3}$ Keith hamilton and Richard Langhorne, The Practice of Diplomacy: Its Evolution, Theory and Administration (London and New York: Routledge, 1995)
} 
kelompok- kelompok, atau entitas- entitas yang terasing, ${ }^{4}$ terutama, jika ada batas identitas dan batas itu dilintasi. ${ }^{5}$

Abad keduapuluh bahkan dicirikan oleh banyaknya diplomasi multilateral atau diplomasi konferensi. ${ }^{6}$ Dalam situasi itu, aktor negara dan bukan negara berdiplomasi. Salah satu yang timbul kemudian adalah pertalian dan hubungan simbiosis yang tumbuh antar kedua aktor ini. Oleh Hocking fenomena ini disebutnya diplomasi katalitik. ${ }^{7}$

Seiring tumbuh kembang praktek diplomasi ini maka terbentuk jaringan transnasional. Jaringan bisa didefinisikan sebagai bentuk- bentuk organisasi yang ditandai dengan pola- pola komunikasi sukarela, timbal balik, dan horisontal. ${ }^{8}$ Jaringan ini bisa berisi individu tetapi juga bisa berisi organisasi- organisasi formal.

Jaringan internasional dan anggotanya biasanya memiliki kesamaan nilai- nilai tertentu, keyakinan prinsip dan wacana bersama. ${ }^{9}$ Mereka bertindak didorong oleh motivasi yang bisa bersifat instrumental yakni mengejar kepentingan mereka seperti ditunjukkan oleh perusahaan internasonal. Motivasi lain lebih bersifat kebaikan bersama. Dengan kata lain, ada aktor yang mengejar keuntungan dan ada yang tidak mengejar keuntungan.

Pada tipe kedua yakni jaringan transnasional yang tidak mengejar keuntungan biasanya terdapat advokasi jaringan, kelompok epistemik, dan aktor transnasional lain. Aktivitas mereka seringkali memiliki dampak pada kebijakan negara, penciptaan norma internasional, dan difusi norma ke

\footnotetext{
${ }^{4}$ James Der Derian, Mediating estrangement: A Theory for Diplomacy dalam Review of International Studies (1987 13 (2) h. 91-110)

${ }^{5}$ Costantinou, Loc. Cit., h.113.

${ }^{6}$ Johan Kauffman, Conference Diplomacy: An Introductory Analysis 3rd Edition (London: MacMillan, 1996)

${ }^{7}$ Brian Hocking, Catalytic Diplomacy: Beyond Newness and Decline dalam Jan Melissen (ed.), Innovation in Diplomatic Practice (London: MacMillan, 1999)

${ }^{8}$ Margareth Keck and Kathryn Sikkink, Activist Beyond Borders: Transnational Advocacy

Networks in International Politics (Ithaca: Cornell University Press, 1998),h. 8.

${ }^{9}$ Ibid, h. 2.
} 
praktek domestik. ${ }^{10}$ Artinya kekuatan pengetahuan dan keyakinan prinsip mereka turut memberi pengaruh penting pada politik dunia.

Adapun proses komunikasi yang digunakan mereka bisa berupa mobilisasi sosial, protes, dan tekanan. Mereka juga bisa mengkerangka ulang (reframing) isu- isu untuk memobilisasi orang- orang pada ide atau norma baru. Jaringan transnasional dan komunitas epistemik juga sering memakai kekuatan argumen. Mereka membenarkan klaim mereka dan membujuk audience untuk mengubah kepentingan dan kebijakan mereka. Dalam pandangan Finnemore, mereka bertindak sebagai guru norma. ${ }^{11}$

Untuk memahami tindakan para agamawan tersebut, tulisan ini melihatnya dalam kerangka perilaku berbasis norma (norm- based behaviour). Pemikiran konstruktivisme ini memandang bahwa tindakan actor didorong oleh motivasi ideasional berdasar logika kepantasan dan bukan alasan kepentingan materi (logika konsekuensi). ${ }^{12}$ Menurut Finnemore dan Sikkink pengaruh norma bisa dilihat melalui proses tiga tahap $^{13}$ yaitu norm emergence/ origin/ construction), cascading, dan internalization.

\section{B. METODE PENELITIAN}

Melalui pendekatan institusi agama, peneliti ingin melihat alasan dan peran entitas- entitas keislaman dalam diplomasinya.Oleh karena itu, yang menjadi fokus dalam penelitian ini adalah tentang motivasi dan kontribusi NU sebagai organisasi Islam dalam diplomasi melalui forum konferensi. Dalam penelitian ini penulis menggunakan tipe penelitian deskriptif

\footnotetext{
${ }^{10}$ Seperti karya Ann Florini (ed.), The Third Force: The Rise of Transnational Civil Society (Tokyo and Washington: Japan center for International Exchange and Carnegie Endowment for International Peace, 2000)

${ }^{11}$ Martha Finnemore, International Organizations as Teacher of Norms: The UNESCO and Science Policy dalam International Organization, 1993, 47 (4) h. 565-597.

${ }^{12}$ Kegley, Charles W., Eugene Wittkopf. World Politics: Trend and Transformation (New York: ST Martin,s Press., 2010)

${ }^{13}$ Martha Finnemore and Kathryn Sikkink, International Norm Dynamics and Political Change, International Organization, Vol. 52, No. 4, International Organization at Fifty: Exploration and Contestation in the Study of World Politics. (Autumn, 1998), pp. 887-917.
} 
kualitatif. Adapun sumber data yang akan digunakan adalah sumber data primer dan sumber data sekunder. Data primer didapatkan dari rekaman pidato tokoh kunci seperti KH Hasyim Muzadi dan KH Said Aqil Siraj. Selanjutnya, untuk memperoleh data sekunder, penulis menggunakan sumber data berupa dokumen dan publikasi resmi terutama tentang konteks dan konten diplomasi NU.

Data yang terkumpul akan dianalisis secara kualitatif. Tahapannya antara lain, pertama, reduksi data yang bertujuan untuk menyeleksi, memilah, memilih, dan mengorganisasikan data ke dalam pola kategori dan tema tertentu. Kedua, display data yaitu menyajikan data dalam bentuk model, sinopsis, dan matriks. Ketiga, adalah tahap penarikan kesimpulan.

\section{PEMBAHASAN}

\section{C.1. Bentuk- bentuk Konferensi}

\section{C.1.1. International Conference of Islamic Scholars (ICIS)}

Forum konferensi kiai pertama yang diselenggarakan di era reformasi adalah International Conference of Islamic Scholars (ICIS) yang didirikan pada 24 Pebruari 2004 di Jakarta. Konferensi ini dihadiri ulama- ulama besar Syekh Wahbah Zuhaili (Syiria) dan Syekh Ali At Taskhiri (Iran) serta 67 ulama dan 47 negara, cendekiawan dan pengamat Islam dunia lainnya yang memiliki kompetensi yang diakui secara internasional menjadi legitimasi forum ini.

Prinsip pemikiran ICIS adalah mempromosikan pemikiran moderat Islam dan kebangsaan. Adapun visi ICIS adalah menjadi lembaga yang mentransformasikan kemuliaan nilai-nilai Islam moderat sebagai pedoman hidup individual dan etika sosial untuk menciptakan tatanan dunia yang damai dan berkeadaban. Adapun misinya adalah mengaktualisasikan Islam Rahmatan Lil'alamin, mengembangkan dan menyebar serapkan nilainilai Islam Aswaja, mendinamisir ulama dalam mewujudkan tatanan masyarakat yang berkeadilan dan berkeadaban, menjembatani para Ulama untuk mengembangkan inisiatif penyelesaian konflik menuju perdamaian, 
memperkuat jaringan nasional dan internasional dengan lembaga dan tokohtokoh yang peduli dan mengikatkan diri pada perdamaian. ${ }^{14}$

Misi pertama dan kedua menunjukkan motivasi ideasional untuk menyebarkan Islam moderat. Misi ketiga hingga kelima menunjukkan jaringan sekaligus mekanisme sosialisasi dan pelembagaan dalam penyebaran norma tersebut. Sebagaimana dikatakan KH Hasyim Muzadi, ICIS merupakan forum konferensi ulama-ulama dunia lintas negara dan lintas madzhab dibentuk dengan dua tujuan. Yang pertama adalah bagaimana menampilkan Islam yang rahmatan lil alamin dan tujuan yang kedua adalah untuk memperkenalkan bahwa negara Pancasila model Indonesia adalah alternatf dari negara agama dan negara sekuler, dimana Indonesia berada di tengah dan penduduknya bisa hidup dalam pluralitas dengan aman. ${ }^{15}$ Tujuan pertama tersebut secara tegas menunjukkan upaya sosialisasi norma ke ranah global. Dalam konferensi ICIS pertama ini lahir Jakarta Declaration di mana pemikiran keislaman rahmatan lil alamin menjadi spirit utama di dalam setiap butir deklarasi itu. Deklarasi Jakarta ini menunjukkan terbangunnya jaringan ulama Islam yang memegang norma. Ia juga menunjukkan motivasi untuk mengadopsi norma tersebut.

Jaringan yang terbangun kembali dikuatkan dengan perhelatan ICIS II yang diselenggrakan di Jakarta pada 20- 22 Juni 2006. ICIS II menghasilkan sebuah dokumen bertajuk Programme of Action to Uphold Islam as Rahmatan lil Alamin toward Global Justice and Peace yang terdiri dari 17 paragraf pembuka dan 37 paragraf substantif. ICIS kedua ini dihadiri oleh lebih dari 300 scholars dari 54 negara, tidak hanya dari negara yang mayoritas penduduknya beragama Islam, tetapi juga dari negara di mana minoritas muslim berada.

Sebagai bagian dari langkah kongkret yang disepakati dalam programme of action itu, ICIS II telah memberi mandat kepada Sekretaris Jenderal untuk melakukan hal-hal sebagai berikut. Pertama, studi mengenai

\footnotetext{
${ }^{14}$ http://web.isanet.org/Web/Conferences/GSCIS\%20Singapore\%202015/Archive/80d19277-25a64fc4-8097-1c55d62c1744.pdf

${ }^{15}$ Ibid.
} 
langkah-langkah paraktis guna mengambil sebesar-besarnya faedah dari globalisasi yang terus bergilir agar pemenuhan hak-hak politik, ekonomi dan budaya umat Islam tetap terjaminKedua, pengembangan arahan-arahan praktis bagi penyelesaian pertikaian dan konflik yang didasarkan pada ajaran-ajaran Islam. Ketiga, pengembangan data-base yang memuat informasi mengenai berbagai organisasi filantropis yang menaruh perhatian terhadap kegiatan-kegiatan umat Islam. Keempat, pengembangan website, yang memuat informasi mengenai pendidikan, lembaga pendidikan tinggi, beasiswa dan bantuan penelitian di negara-negara Islam dan negara-negara lainnya.Kelima, pengembangan kerangka kebijakan yang memajukan nilainilai dan ajaran Islam mengenai berbagai masalah yang terkait dengan kepentingan umat manusia, seperti upaya pemajuan HAM, demokrasi, pendidikan, kesehatan, pemberantasan korupsi dan obat-obatan terlarang. Keenam, suatu studi mengenai kemungkinan dibentuknya sebuah sebuah sekretariat tetap untuk ICIS yang berkedudukan di Jakarta dan berafiliasi sebagai peninjau pada berbagai organisasi internasional, termasuk OKI dan PBB.

ICIS III diselenggarakan pada 30 Juli sampai 1 Agustus 2009 di Hotel Borobudur Jakarta Pusat. Kegiatan ini mengambil tema Islam as Rahmatan Lil 'Alamin: Peace Building and Conflict Prevention in The Muslim World. Penyelenggaraan ICIS III bertujuan untuk mengurai dan menganalisis anatomi konflik dalam dunia Islam, sekaligus merekam upaya menyelesaikan konflik dan mewujudkan perdamaian.

Pada penyelenggaraan ICIS III dihasilkan keputusan bersama dalam bentuk "Pesan Jakarta". Pesan itu antara lain berisi tentang perlunya menegakkan Islam sebagai Rahmatan lil Alamin melalui pembangunan perdamaian dan pencegahan konflik di Dunia Muslim. Konferensi International Ulama dan Cendekiawan Islam ketiga juga menegaskan kembali keyakinan bahwa nilai-nilai dan ajaran Islam mewajibkan ummah untuk mendorong perdamaian, keadilan, kebebasan, moderasi, toleransi, 
keseimbangan dan konsultasi serta kesetaraan, sebagai landasan harkat dan martabat manusia.

ICIS keempat diselenggarakan di Ponpes Salafiyah-Syafi'iyah Sukorejo, Situbondo, Jawa Timur pada Maret 2014.Adapun tema konferensi adalah Penguatan Jaringan Antarulama dan Cendekiawan Muslim untuk Meneguhkan Nilai-nilai Islam Moderat. ICIS keempat menghasilkan sembilan rekomendasi hasil diskusi ulama- ulama se-dunia itu terkait rumusan dan sikap moderat sunni terhadap realitas kekinian, di bidang pemikiran, ekonomi, politik, pendidikan, tradisi dan budaya, dan lainnya. Intinya, moderatisme Islam tidak menampik perkembangan yang terjadi, tapi tetap menjadikan nash atau dalil agama sebagai landasan.

Dengan sembilan rekomendasi itu diharapkan dapat membimbing dan membina umat Islam dengan cara menyebarkan pemikiran Islam yang moderat untuk membentuk generasi yang konstruktif, sehingga dapat menyelesaikan masalah perbedaan dengan cara dialog. Adapun sembilan rekomendasi yang dihasikan adalah, pertama, menyepakati yang dimaksud dengan moderasi adalah suatu kebenaran di antara dua kebathilan.Sikap moderasi dimaksud untuk bisa dilakukan oleh setiap individu dalam pemikiran, akhlak, prilaku, dan segala tindakannya guna melestarikan kebaikan individu maupun kelompok masyarakat dengan tanpa adanya radikalisme atau liberalisme.

Kedua, moderasi pemikiran yaitu suatu ide yang meyakini puritansi nas-nas agama dalam satu sisi, serta meyakini adanya korelasi nas suci dengan keadaan waktu dan tempat.Dalam hal ini, tugas ulama dan umat Islam adalah memberikan pemahaman arti nas suci pada tataran praktis pada semua sendi kehidupan. Ketiga, moderasi dalam upaya penerapan syar'iyah, yakni dengan menjauhkan sikap kekerasan dan berlebihan. Di sinilah bias dipahami sesungguhnya Islam adalah agama damai dan rahmat, serta jauh dari sifat radikalisme dan liberalism. Keempat, moderasi dalam bertoleransi yakni dengan memaklumi dan mentolerir adanya eksistensi agama-agama lain dalam suatu negara.Sebab multi agama dalam kehidupan adalah 
keniscayaan atau sunnatullah. Kelima, moderasi dalam berpolitik yakni penguatan terhadap teori demokrasi dan hak asasi manusia (HAM).Disebutkan, Islam tidak hanya mengajarkan demokrasi dan HAM, tetapi sebuah konsep universal dengan menghargai sikap demokrasi menggunakan konsep syuro, dan menempatkan kedudukan manusia dan hak-haknya pada tempat yang hakiki. Keenam, moderasi dalam pendidikan dan pengajaran, yaitu peningkatan pendidikan bagi umat Islam dari semua disiplin ilmu.Umat Islam kini sedang tertantang dalam bidang ilmu, teknologi, dan informasi. Realitasnya kaum terpelajar dan terdidik dengan kualifikasi ilmu yang memadai tidak sebanding dengan jumlah umat Islam sehingga perlu disiapkan kader yang kompeten sehingga mampu berkompetisi. Ketujuh, moderasi dalam ekonomi, yakni menjajikan alternative peningkatan kesejahteraan bagi umat Islam dengan system ekonomi yang sesuai syariah. Kedelapan, moderasi dalam tradisi dan budaya dengan menyebarkan pemikiran moderat dengan sikap toleran.Dipaparkan, saat ini kebanyakan nilai-nilai tradisi dan budaya terpasung pada politik praktis yang dikendalikan hawa nafsu yang menyebabkan pada radikalisme dan liberalisme. Karena itu, menjadi kewajiban bagi ulama dan cendekiawan untuk memberikan pencerahan kepada masyarakat mengenai pemikiran dan sikap moderat dalam mempertahankan tradisi, budaya dalam menghadapi transnasional. Kesembilan, khusus ditujukan kepada para ulama, cendekiawan, dan para pejabat pemerintahan untuk melaksanakan keputusan ini. Serta menjaga jaringan antar ulama dan cendekiawan muslim dalam pengaplikasikan poin-poin hasil konferensi. ${ }^{16}$

\section{C.1. 2. Al-Multaqo as-Sufy al-Alamy/World Sufi Forum}

Selain forum ICIS, Nahdlatul Ulama memiliki forum yang bernama Al-Multaqo as-Sufy al-Alamy (Konferensi Sufi Internasional). Forum

\footnotetext{
${ }^{16}$ https://www.bangsaonline.com/berita/918/inilah-sembilan-rekomendasi-konferensi-ulamainternasional?browsefrom=mobile diakses pada tanggal 26 Juli 2017 pukul 13.46 WIB.
} 
internasional tersebut juga berkontribusi mensosialisasikan norma rahmatan lil alamin dengan mendorong ide Islam dalam perdamaian internasional khususnya di dunia Islam. Ia menjadi jaringan ulama moderat dari kalangan pengamal tasawuf yang menyuarakan perdamaian dan rahmatan lil alamin yang dimotori oleh Jam'iyah Ahlith Thariqah Al-Mu'tabarah An-Nahdiyah (Jatman) di bawah PBNU. ${ }^{17}$

Kegiatan itu bertujuan untuk menggali potensi yang terkandung dari nilai - nilai ajaran tasawuf dan tarekat untuk membantu mewujudkan perdamaian dunia yang semakin jauh dari angan- angan. Adapun dalam pertemuan itu dibahas tentang pentingnya mengupayakan perdamaian dunia yang digali dari nilai - nilai ajaran tasawuf. Disamping itu dirumuskan pula langkah bersama untuk mengurangi fanatisme kelompok, menghimpun silsilah sanad para mursyid dari semua aliran tarekat di seluruh dunia, serta saling bertukar informasi seputar dunia tasawuf dan tarekat dari berbagai negara.

Kegiatan ini bisa disebut juga dalam kategori komunitas epistemik di bidang kesufian karena dihadiri para ulama sufi dan mursyid tarekat dari dalam dan luar negeri. Di antaranya Syaikh Hisyam Kabbani (Amerika, Khalifah Naqsyabandi Haqqani), Syaikh Rojab Dib An-Naqsyabandi (Syria, Mursyid Tarekat Naqsyabandi), Habib Zaid bin Abdurrahman bin Yahya (Yaman), Syaikh Abdurohim Ar-Rukainy (Sudan, Mursyid Tarekat Qur'aniyah As-Sunniyah Al-Muhammadiyah aar-Rukainiyah), Syaikh Jibril Fuad al-Hadad (Brunei, penanggung jawab dakwah Asia Tenggara Naqsyabandi Haqqani), Syaikh Fuad Suhaimi (utusan khusus Pemimpin Libya Moammar Qadafi), dan Syaikh Musthafa Mas'ud (Amir Naqsyabandi Haqqani Indonesia). Dari dalam negeri hadir para mursyid tarekat - tarekat mu'tabarah di bawah naungan NU. Mereka berjumlah 50 orang. Ditambah para pengurus Idaroh Aliyah dan Idaroh Wustho Jaatman se-Indonesia sehingga jumlah mereka sekitar 300 orang. Hadir pula seorang pengamat dari Jepang Prof Tonaga.

\footnotetext{
${ }^{17}$ Majalah Nahdlatul Ulama Aula No. 08 Tahun XXXIII Agustus 2011 h. 10-16.
} 
Rais Am PBNU, Dr KH MA Sahal Mahfudz, menilai penggalian kembali nilai - nilai tasawuf untuk membantu perdamaian dunia saat ini sangat penting. ${ }^{18}$ Apalagi dunia sedang dilanda dekadensi moral, pornografi, korupsi, pelanggaran nilai - nilai dan norma agama Islam. Stigma negatif juga semakin melekat pada umat Islam, akibat sikap radikal yang dilakukan sebagai kecil umat Islam. Oleh karena itu, pendekatan tasawuf yang mengedepankan kejernihan hati dan kebenaran universal menjadi sangat penting dilakukan. Apalagi di Indonesia tasawuf turut berperan penting dalam membebaskan diri dari penjajahan.

Ketua Umum PBNU, Dr KH Said Aqiel Sirodj, MA, menjelaskan, kembali kepada nilai - nilai ajaran tasawuf saat ini adalah sangat penting karena terkait toleransi dan perdamaian. Orang NU dikenali memiliki toleransi yang tinggi karena di dalamnya mengalir nilai - nilai tasawuf yang kuat. Menurutnya, tanpa tasawuf orang akan sulit toleran.

Konferensi Internasional Ulama digelar oleh Jamiyyah Ahlit Thoriqoh al Mutabaroh an Nahdhiyah (Jatman) bersama Kementerian Pertahanan RI pada tahun 2016 diselenggarakan dua kali pada bulan Januari dan bulan Juli. Konferensi Ulama Internasional Pertama yang dilaksanakan pada 15 Januari 2016 membuahkan hasil yaitu Sembilan Konsensus Bela Negara dan ditandatangani oleh para ulama. Mereka adalah Habib Muhamad Luthfi Bin Yahya (Indonesia), Dr. Syekh Muhammad Adnan Al-Afiyuni (Suriah), Dr. Syekh Aziz al-Idrisi (Maroko), Prof. Dr. Syekh Muhammad Fadhil alJailany (Turki). Habib Zaid bin Abdurahman bin Yahya (Yaman),. Dr. Syaikh Aziz Abidin (USA), dan Syekh 'Aun Mu'in al-Quddumi

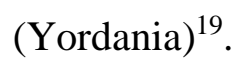

Konferensi Ulama Internasional kedua yang dilaksanakan pada 2729 Juli 2017 membuahkan hasil 15 konsensus. Kelima belas konsensus tersebut dibacakan oleh ulama asal Syiria Syekh Muhammad Adnan al-

\footnotetext{
${ }^{18}$ Ibid.

${ }^{19}$ Mega Dhian \& Wicaksono Rhony, www.timesindonesia.co.id "Para Ulama Internasional Sepakati Konsensus Bela Negara”, Sabtu, 16 Januari 2017, 22.37. diakses pada Senin, 11 September 2017, 11.32.
} 
Afyuni selaku ulama yang menjadi mufti di Damaskus ${ }^{20}$. Konferensi ketiga telah diadakan pula pada 14-18 Januari 2018 dengan mengangkat tema-tema yang berkaitan dengan nasionalisme seperti tentang "Bela Negara".

Konferensi Ulama Sufi Internasional (World Sufi Forum) kembali diselenggarakan pada 8-10 April 2019 di Pekalongan Jawa Tengah. Kegiatan yang digelar Jamiyyah Ahlit Thoriqoh al Mutabaroh an Nahdhiyah (Jatman) bekerja sama dengan Kementerian Pertahanan RI ini mengangkat tema 'Peran Tasawuf dalam Menciptakan Kebahagiaan Umat Manusia dan Keselamatan Negara'.21

Selain ribuan mursyid dan pengurus organisasi pengamal tasawuf tanah air, lebih dari 96 ulama sufi internasional masyhur dan kompeten dipastikan hadir seperti dari Mesir, Saudi, Maroko, Pakistan, Syiria, Yaman, Yordania, Libanon, hingga beberapa negara Eropa dan Amerika. Bahkan Grand Syekh al Azhar Syeikh Ahmed al-Tayeb yang beberapa waktu lalu menandatangani Deklarasi Persaudaran Kemanusiaan bersama Paus Fransiskus juga dijadwalkan memberikan paparan.

Dengan diadakannya konferensi ulama internasional oleh JATMAN tersebut, Menurut Dr. Hamdani selaku pengurus dari JATMAN sangat mengapresiasi adanya konferensi ulama internasional yang digagas oleh Habib Muhammad Luthfi bin Yahya (Ra'is Aam JATMAN) "saya pikir ini adalah sejarah, sehingga thariqoh tidak hanya dikonotasikan sebagai orangorang ahli dzikir, tetapi juga memiliki komitmen nasionalisme, bahkan ini mendunia, dengan acara konferensi internasional ulama Thariqoh sedunia ini, menunjukan bahwa ahli thariqoh itu juga berkontribusi kepada dunia dalam hal peradaban dan kemanusiaan yang berdasarkan atas perdamaian dunia $^{22}$,

\footnotetext{
${ }^{20}$ Muiz Abdul \& Fathony, www.nu.or.id "Ini 15 Konsensus Hasil Konferensi Ulama Internasional Bela Negara” Jum'at, 29 Juli 2017, 23.51 diakses pada Senin, 11 September 2017, 11.38.

${ }^{21}$ Andi Purwono, Diplomasi Ulama Sufi di Opini Koran Tribun Jateng 7 April 2019.

${ }^{22}$ Sukma Ahmad \& Ainun Yatimul, www.timesindonesia.co.id "Ulama Thariqoh memiliki Komitmen Nasionalisme”, Selasa, 26 Juli 2016, 20.15, diakses pada Senin, 11 September 2017, 13.43
} 
Thoriqoh (tarekat) adalah suatu kelompok organisasi yang melakukan amalan-amalan zikir tertentu, dan menyampaikan suatu sumpah yang formulanya telah ditentukan oleh pimpinan organisasi tarekat tersebut ${ }^{23}$. Selain itu tarekat berarti jalan atau cara untuk mencapai tingkatan-tingkatan (maqamat) untuk mendekatkan diri kepada Tuhan ${ }^{24}$. Tarekat Muktabaroh adalah tarekat yang mutashil (tersambung) sanadnya kepada Nabi Muhammad SAW,

\section{C.1.3. International Summit of the Moderate Islamic Leaders (ISOMIL)}

Jika di era KH Hasyim Muzadi Nahdlatul Ulama memiliki forum ICIS, di era KH Said Aqil Siraj forum serupa bernama International Summit of the Moderate Islamic Leaders (ISOMIL1).ISOMIL merupakan forum inisiatif Pengurus Besar Nahdlatul Ulama (PBNU) yang didorong atas keprihatinan NU terhadap situasi dunia Islam yang dilingkupi perpecahan, bahkan perang saudara. ${ }^{25}$ Lewat forum ini, NU berharap hal-hal positif dari Islam di Indonesia dapat menjadi inspirasi bagi umat Islam dari berbagai belahan dunia.

Kegiatan tersebut diselenggarakan di Gedung Jakarta Convention Hall (JCC), pada 9-11 Mei 2016 ini, diikuti oleh sekitar 400 peserta, dari berbagai negara, terutama Timur Tengah, Eropa, Amerika, Australia, perwakilan negara-negara Asia, dan kiai-kiai Indonesia. Melalui agenda Isomil, Kiai Said menyatakan bahwa PBNU berusaha mendorong perdamaian di dunia internasional dengan berusaha menawarkan Islam Nusantara sebagai inspirasi peradaban dunia. ${ }^{26}$

Konferensi tersebut menghasilkan 16 deklarasi Nahdlatul Ulama (NU) yang poinnya merupakan hasil konsultasi dari para ulama yang hadir dan

${ }^{23}$ Mulyati Sri, “Tarekat-Tarekat Muktabaroh Di Indonesia”, Prenada Media, Jakarta, 2005, hal 9. ${ }^{24}$ Red, www.nu.or.id "Tariqoh Al Mu'tabaroh Dari Waktu Ke Waktu” Kamis, 31 Maret 2005, 10.22, diakses pada Sabtu, 11 November 2017, 23.45.

${ }^{25}$ http://www.nu.or.id/post/read/68091/isomil-berakhir-dengan-deklarasi-nahdlatul-ulama diakses pada 17 November 2016 jam 13.22 WIB.

${ }^{26}$ http://www.nu.or.id/post/read/68033/isomil-nu-dorong-perdamaian-dunia diakses pada 17 November 2016 jam 13.27 WIB. 
para ahli yang dilibatkan. ${ }^{27}$ Deklarasi tersebut berisi enam belas poin, ${ }^{28}$ yang antara lain berisi tawaran wawasan dan pengalaman Islam Nusantara kepada dunia sebagai paradigma Islam yang layak diteladani, bahwa agama menyumbang kepada peradaban dengan menghargai budaya yang telah ada serta mengedepankan harmoni dan perdamaian. Melalui berbagai perhelatan di atas, ulama NU tidak hanya berusaha menjadikan Islam sebagai ajaran universal, menggerakkan jejaring ulama Internasional, serta berusaha mengerem laju radikalisme berbaju agama, melainkan lebih dari itu, para individu Nahdlatul Ulama maupun secara organisatoris bergerak dinamis mewujudkan perdamaian dunia. ${ }^{29}$

\section{C.2. Motivasi dan Kontribusi}

Dari paparan deskriptif di atas, kita bisa melihat pada aspek motivasi bahwa para kiai Nahdlatul Ulama pengaggas serta para peserta konferensi didorong oleh kepentingan yang berasal dari norma yang mereka yakini. Ini sejalan dengan rgumen konstruktivisme bahwa tindakan dipengaruhi kepentingan, dan kepentingan itu dipengaruhi norma dan identitas. Para kiai berkepentingan untuk menunjukkan Islam yang sebenarnya kepada dunia. Mereka juga menunjukkan diri sebagai pengikut Islam rahmatan lil alamin (norm follower) dan berupaya menyebarkannya.

Dalam kerangka konstruktivisme juga kita melihat bahwa motivasi yang mendorong mereka untuk tunduk pada norma yaitu legitimasi, reputasi, dan penghormatan. Pertama, legitimasi merupakan hal yang penting bagi aktor, di mana sumber legitimasi internasional memiliki peranan penting dalam membentuk perilaku mereka. Para anggota tidak hanya menginginkan keberadaannya diakui sebagai bagian dari komunitas yang merugikan namun juga memberi rahmat.

\footnotetext{
${ }^{27}$ http://khazanah.republika.co.id/berita/dunia-islam/islam-nusantara/16/05/11/o6z3o3313-isomilhasilkan-16-deklarasi-nu diakses pada 17 November 2016 jam 13.25 WIB

${ }^{28}$ http://www.nu.or.id/post/read/68092/inilah-naskah-lengkap-deklarasi-nahdlatul-ulama-kepadadunia

${ }^{29}$ http://www.moslemforall.com/peran-nu-dalam-mewarnai-dunia/
} 
Ini ditunjukkan dengan deklarasi dan upaya untuk mendapat pengakuan dari organisasi- organisasi internasional yang lebih dulu mapan seperti Rabithah Alam Islami, OKI, PBB, dan WCRP. Organisasiorganisasi internasional ini seakan berperan sebagai "pemberi label"sekaligus "norm teacher" kepada negara dan aktor lain untuk menjadi bagian dari aktor yang menerima atau menolak norma. Dalam konteks seperti itu lah motivasi aktor untuk memperoleh legitimasi internasional berlangsung karena ada biaya besar yang harus ditanggung oleh aktor jika bertentangan dengan norma yaitu mendapat label sebagai "rogue actor". Mereka akan kehilangan reputasi, kepercayaan dan kredibilitas mereka dalam dunia internasional.

$\underline{\text { Kedua, }}$ motivasi reputasi berkaitan dengan bentuk penilaian aktor lain dalam hubungan antarnegara dalam suatu komunitas. Menurut Axelrod, sebagaimana dikutip oleh Finnemore dan Sikkink, kesesuaian merupakan "bukti sosial", aktor mengikuti norma untuk menunjukkan bahwa mereka telah beradaptasi dan menjadi bagian dari lingkungan sosial. Ketiga, penghormatan berhubungan dengan legitimasi dan kesesuaian, namun sifatnya lebih dalam karena motif penghormatan mengindikasikan bahwa pemimpin negara terkadang mengikuti norma yang ada agar dinilai baik oleh negara lain, dan mereka ingin beranggapan baik terhadap diri mereka sendiri.

Adapun beberapa kontribusi penting diplomasi konferensi para kiai ini

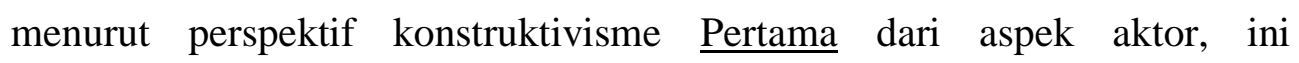
menunjukkan terbangunnya jaringan ulama Islam yang memegang norma pembawa rahamt bagi semua. Kedua dari aspek motivasi, mereka yang menandatangani deklarasi seperti ulama besar Syekh Wahbah Zuhaili (Syiria) dan Syekh Ali At Taskhiri (Iran) serta lainnya memiliki legitimasi untuk menjadi ulama Islam yang rahmatan lil alamin, reputasi sebagai norm enterpreneurs, sekaligus menghargai norma tersebut. Ketiga, dari aspek mekanisme, forum ini menjadi wahana sosialisasi yang penting. Apalagi jika kita mencermati upaya-upaya lanjutannya membentuk organizational 
platform. Ia tidak sekedar menjadi corong tapi sekaligus strategi dalam mensosialisasikan norma ke tingkat internasional.

Ini dibuktikan dengan langkah ICIS selanjutnya yang pada akhirnya mengaitkan dirinya dengan organisasi internasional lain yang telah mapan. ICIS menjadi lembaga internasional yang terdaftar di OKI (Organisasi Konferensi Islam, Organization of the Islamic Conference) dan Rabithah Alam Islami (Liga Muslim Dunia) yang berpusat di Makkah dan terdaftar di PBB. ${ }^{30}$ Bahkan tidak sekedar mengaitkan, namun organisasi tersebut juga dimanfaatkan dalam upaya mempromosikan Islam rahmatan lil alamin. ${ }^{31}$

Kehadiran banyak peserta internasional bereputasi dan kesesuaian mereka dengan norma tersebut menunjukkan kemampuan norm entrepreneurs mengemas isu secara baik dalam mempromosikan norma secara internasional. Dengan kata lain, mereka berhasil mendapatkan kepercayaan dari peserta tokoh dan organisasi yang berbeda- beda budaya dan konteks sosial.

Bagi Indonesia, diplomasi ulama melalui konferensi ini juga sarat makna. Pertama, ia menegaskan karakter washathiyah/ moderat Islam Indonesia yang terbukti bisa berjalan seiring dengan demokrasi dan modernitas. Identitas ini menjadi pembeda sekaligus menempati posisi sangat penting sebagai modal diplomasi Indonesia di fora internasional. Ia menjadi bagian dari soft power kita dalam menarik dan memenangkan hati dan pikiran pihak lain sehingga bersahabat dan berhubungan baik dengan kita.

Kedua, pemikiran dan rekomendasi yang dihasilkan menjadi masukan berharga bagi para pembuat kebijakan. Ulama seringkali memberi informasi dan pandangan dunia yang melengkapi informasi diplomasi jalur pertama.

\footnotetext{
${ }^{30}$ Hasyim Muzadi, Islam Rahmatan Lil Alamin. Pidato pengukuhan doktor honoris causa oleh UIN Sunan Ampel 2006.

${ }^{31}$ Hasyim Muzadi, Islam in Indonesia: Toleranceand Moderation dalam Umar Hadi, Abdul Mu'ti et.al., Islam in Indonesia: A to Z Basic Reference (Jakarta: Directorate of Public Diplomacy, Ministry of Foreign Affairs of the Republic of Indonesia and Center for Dialogue and Cooperatioan among Civilization/ CDCC, 2009), h. 2006-2009). Lihat pula rekaman pidato KH Hasyim Muzadi di Universitas Wahid Hasyim tahun 2014 dan Pidato KH Said Aqil Siraj dalam Wisuda Unwahas tahun 2015.
} 
Bahkan terkadang mereka juga berperan menjadi aktor pengganti dalam hal khusus yang tidak bisa dilakukan dijangkau diplomat resmi. Kementerian luar negeri misalnya menyebut kaum agamawan moderat ini sebagai tandem dan mitra. Hal ini menunjukkan bahwa ide agama bisa berperan sebagai motivasi yang menginspirasi dan kaum agamawan memainkan peran yang meningkat dalam diplomasi.

Sebagai contoh, komunikasi KH Hasyim Muzadi dan Menlu Hassan Wirajuda sejak 2003 menjadi awal kemunculan frase Islam washathiyah/ moderat dalam kebijakan luar negeri Indonesia di era reformasi. Dikonstruksi sejak era Presiden Megawati, Islam moderat ini kemudian diproyeksikan dalam berbagai kebijakan luar negeri era Soesilo Bambang Yudhoyono dan juga Joko Widodo kini. Disertasi penulis (2018) menunjukkan ada pertautan antara motivasi ideasional agama dan motivasi instrumental kepentingan nasional dalam hal tersebut. Prakarsa Ketua Umum PBNU Periode 1999 - 2010 KH Hasyim Muzadi bersama dengan Menteri Luar Negeri RI periode 2001 - 2009 Hasan Wirajuda ${ }^{32}$ dan Presiden Megawati ${ }^{33}$ menunjukkan hal itu.

Ketiga, di ranah implementasi politik luar negeri, jaringan ulama yang terbangun pada gilirannya terbukti mempertajam diplomasi Indonesia. Sejumlah riset mencatat tinta emas kontribusi diplomasi tokoh masyarakat seperti ini dalam menunjang keberhasilan pengakuan kemerdekaan Indonesia 1945 maupun kesuksesan Konferensi Asia Afrika 1955 misalnya. Demikian pula kebijakan- kebijakan mempromosikan identitas Islam moderat Indonesia dan kebijakan menciptakan harmoni Islam- Barat dan intra-Dunia Islam di era reformasi.

Dalam pandangan Kiai Hasyim Muzadi, Indonesia sebagai negara berpenduduk muslim terbesar didunia, tidak bisa berpangku tangan melihat

\footnotetext{
${ }^{32} \mathrm{http}: / /$ web.isanet.org/Web/Conferences/GSCIS\%20Singapore\%202015/Archive/80d19277-25a6$4 \mathrm{fc} 4-8097-1 \mathrm{c} 55 \mathrm{~d} 62 \mathrm{c} 1744 . \mathrm{pdf}$

${ }^{33}$ Hasyim Muzadi, ICIS, Islam Moderat, dan Interfaith Dialogue dalam Tabloid Diplomasi Kemenlu Juni 2010. Lihat juga Dr. KH. Ahmad Hasyim Muzadi, Sekjen Internatonal Conference of Islamic Scholars (ICIS), Sudah Tepat Diplomasi Publik Menjual Islam Moderat dalam dalam Tabloid Diplomasi No. 52, Tahun VI, 15 Pebruari - 14 Maret 2012, h. 6.
} 
penderitaan negara-negara muslim yang ada. ${ }^{34}$ Pernyataan ini menunjukkan rasa berkewajiban untuk bertindak ketika melihat penderitaan yang ada. Perasaan berkewajiban ini mengindikasikan bekerjanya norma.

Karena itu, para kiai Indonesia melalui beberapa forum tersebut tidak sekedar melakukan konferensi tetapi kemudian juga mengulurkan bantuan penyelesaian konflik. Dengan demikian apa yang dilakukan melalui diplomasi konferensi para kiai ini mencakup dua hal sekaligus. Pertama ia berperan sebagai forum konferensi yang mensosialisasikan norma. Kedua, ia juga menjalankan fungsi second track diplomacy atau diplomasi jalan kedua bagi Indonesia serta mengkampanyekan Islam moderat keluar negeri. ${ }^{35}$

Sebagai contoh, arti penting ICIS dalam konflik Afghanistan bisa dilihat dari temuan bahwa ide keterlibatan Indonesia dalam mendorong perdamaian Afghanistan sudah dimulai sejak ICIS berjalan. Keterlibatan dengan demikian merupakan tindak lanjut implementasi gagasan- gagasan yang dibahas dalam ICIS. ${ }^{36}$ Ide tentang Islam yang rahmatan lil alamin dibawa ke Afghanistan dengan bantuan fasilitasi KBRI.

\section{KESIMPULAN}

Paparan- paparan di atas menunjukkan upaya diplomasi yang dilakukan oleh para kiai organisasi Islam Nahdlatul Ulama dalam menyebarkan norma Islam ke dunia internasional. Hal itu dimotivasi oleh kepentingan yang berasal dari norma yang mereka yakini yaitu ide rahmatan lil alamin. Melalui berbagai perhelatan internasional di atas, organisasi Islam tidak hanya berusaha mensosialisasikan Islam moderat sebagai ajaran universal, tetapi juga menggerakkan jejaring ulama Internasional, serta berusaha mengerem laju radikalisme berbaju agama. Para tokohnya secara pribadi maupun secara organisatoris juga bergerak dinamis mewujudkan perdamaian dunia.

\footnotetext{
${ }^{34}$ Majalah Nahdlatul Ulama Aula No. 12 Tahun XXX Desember 2008, h. 10-22.

${ }^{35}$ Majalah Nahdlatul Ulama Aula No. 08 Tahun XXXII Agustus 2010 h. 26-30.

${ }^{36}$ Rekaman wawancara Achmad Sururi, S.IP.,MA dengan KH As'ad Said Ali, Jakarta 3 Juli 2016
} 
Berkenaan dengan penyebaran norma rahmatan lil alamin tersebut, pada aspek agen/ aktor terlihat bahwa bukan hanya organisasi Islam saja yang berperan dalam proses sosialisasi. Negara kembali berperan turut mensosialisasikan norma rahmatan lil alamin. Pada tahap ini, Indonesia yang sudah mengadopsi normarahmatan lil alamin terlebih dahulu disebut norm leader. Sebagai norm leader, Indonesia membujuk negara-negara lain untuk mengikuti norma yang ada. Ini dibuktikan dengan dukungan yang kuat dari pemerintah pada forum internasional yang diinisiasi Nahdlatul Ulama. Bahkan pemerintah menyebut organisasi keagamaan seperti Nahdlatul Ulama dan Muhammadiyah sebagai mitra. ${ }^{37}$

Dampaknya kita melihat kemunculan jaringan jaringan norm entrepreneurs Islam moderat di tingkat global yang berkomitmen dalam penyebaran dan penerapan norma. Oleh karenanya,forum- forum internasional yang diprakarsai Nahdlatul Ulama menunjukkan $b$ ahwa norma Islam sebagai rahmatan lil-alamin mengalami penyebaran dalam skala luas (cascading) di tingkat dunia. Sosialisasi juga dilakukan secara berangkai berkelanjutan. Oleh karena itu forum ulama/ cendekiawan internasional yang berkelanjutan tersebut menunjukkan komitmen ulama dan cendekiawan akan peran lintas batas ('abra al-hudud/ sans frontiere) dalam membangun perdamaian dan mencegah konflik antara lain melalui fasilitasi dan mediasi.

Bagi Indonesia, diplomasi ulama melalui konferensi ini sangat kontributif. Pertama, ia menegaskan karakter washathiyah/ moderat Islam Indonesia yang terbukti bisa berjalan seiring dengan demokrasi dan modernitas. Kedua, pemikiran dan rekomendasi yang dihasilkan menjadi masukan berharga bagi para pembuat kebijakan. Ketiga, di ranah implementasi politik luar negeri, jaringan ulama yang terbangun pada gilirannya terbukti mempertajam diplomasi Indonesia.

\footnotetext{
${ }^{37}$ Organisasi Islam ini disebut Andri Hadi, Dirjen Informasi \& Diplomasi Publik sebagai tandom kementerian Luar Negeri. Lihat http://www.tabloiddiplomasi.org/previous-isuue/93-juni2010/845-interfaith-dialogue-dalam-konteks-hubungan-internasional.html diakses 19 Februari 2016 jam 15.14 WIB.
} 


\section{PUSTAKA}

Costantinou, Costas M. 1996. On the Way to Diplomacy (Minneapolis University of Minesota Press)

Der Derian, James. 1987. Mediating estrangement: A Theory for Diplomacy dalam Review of International Studies 13 (2) h. 91-110

Finnemore, Martha. 1993. International Organizations as Teacher of Norms: The UNESCO and Science Policy dalam International Organization, 47 (4) h. 565-597.

Finnemore, Martha and Sikkink, Kathryn. 1998. International Norm Dynamics and Political Change, International Organization, Vol. 52, No. 4, International Organization at Fifty: Exploration and Contestation in the Study of World Politics. (Autumn, 1998), pp. 887-917.

Florini, Ann (ed.) 2000. The Third Force: The Rise of Transnational Civil Society (Tokyo and Washington: Japan center for International Exchange and Carnegie Endowment for International Peace, 2000)

Hadi, Umar dan Mu'ti, Abdul (et.al). 2009. Islam in Indonesia: A to Z Basic Reference (Jakarta: Directorate of Public Diplomacy, Ministry of Foreign Affairs of the Republic of Indonesia and Center for Dialogue and Cooperatioan among Civilization/ CDCC, 2009).

Hamilton, Keith and Langhorne, Richard. 1995. The Practice of Diplomacy: Its Evolution, Theory and Administration (London and New York: Routledge)

Kauffman, Johan. 1996. Conference Diplomacy: An Introductory Analysis 3rd Edition (London: MacMillan, 1996)

Keck, Margareth and Sikkink, Kathryn. 1998. Activist Beyond Borders: Transnational Advocacy Networks in International Politics (Ithaca: Cornell University Press, 1998),h. 8.

Kegley, Charles W., Eugene Wittkopf. 2010. World Politics: Trend and Transformation. (New York: ST Martin,s Press.)

Melissen, Jan. 1999. (ed.), Innovation in Diplomatic Practice (London: MacMillan) 
Mulyati, Sri. 2005. Tarekat-Tarekat Muktabaroh Di Indonesia. (jakarta: Prenada Media)

Muzadi, Hasyim . 2006. Islam Rahmatan Lil Alamin. Pidato pengukuhan doktor honoris causa oleh UIN Sunan Ampel.

. 2010. ICIS, Islam Moderat, dan Interfaith Dialogue dalam Tabloid Diplomasi Kemenlu Juni 2010.

2012. Sudah Tepat Diplomasi Publik Menjual Islam Moderat dalam dalam Tabloid Diplomasi No. 52, Tahun VI, 15 Pebruari - 14 Maret 2012

Purwono, Andi. Diplomasi Ulama Sufi di Opini Koran Tribun Jateng 7 April 2019

Majalah Nahdlatul Ulama Aula No. 12 Tahun XXX Desember 2008, h. 10-22.

Majalah Nahdlatul Ulama Aula No. 08 Tahun XXXII Agustus 2010 h. 26-30.

Majalah Nahdlatul Ulama Aula No. 08 Tahun XXXIII Agustus 2011 h. 10-16.

Rekaman wawancara Achmad Sururi, S.IP.,MA dengan KH As'ad Said Ali, Jakarta 3 Juli 2016

Rekaman Pidato KH Hasyim Muzadi di Universitas Wahid Hasyim tahun 2014

Rekaman Pidato KH Said Aqil Siraj dalam Wisuda Unwahas tahun 2015.

Andri Hadi, Dirjen Informasi \& Diplomasi Publik. Lihat http://www.tabloiddiplomasi.org/previous-isuue/93-juni-2010/845interfaith-dialogue-dalam-konteks-hubungan-internasional.html diakses 19 Februari 2016 jam 15.14 WIB.

diakses pada tanggal 26 Juli 2017 pukul 13.46 WIB.

Mega, Dhian \& Wicaksono, Rhony, www.timesindonesia.co.id "Para Ulama Internasional Sepakati Konsensus Bela Negara”, Sabtu, 16 Januari 2017, 22.37. diakses pada Senin, 11 September 2017, 11.32.

Muiz, Abdul \& Fathony, www.nu.or.id "Ini 15 Konsensus Hasil Konferensi Ulama Internasional Bela Negara” Jum'at, 29 Juli 2017, 23.51 diakses pada Senin, 11 September 2017, 11.38.

Sukma Ahmad \& Ainun Yatimul, www.timesindonesia.co.id "Ulama Thariqoh memiliki Komitmen Nasionalisme”, Selasa, 26 Juli 2016, 20.15, diakses pada Senin, 11 September 2017, 13.43 
Qodar, Nafiysul. Kisah KH. Hasyim Muzadi anak tukang roti yang Go Internasional, http://news.liputan6.com/read/2929927/kisah-kh-hasyimmuzadi-anak-tukang-roti-yang-go-internasional, di unduh pada tanggal 14 juni 2017, pukul 20.54 WIB.

http://www.nu.or.id “Tariqoh Al Mu'tabaroh Dari Waktu Ke Waktu” Kamis, 31 Maret 2005, 10.22, diakses pada Sabtu, 11 November 2017, 23.45.

http://www.nu.or.id/post/read/68091/isomil-berakhir-dengan-deklarasi-nahdlatululama diakses pada 17 November 2016 jam 13.22 WIB.

http://www.nu.or.id/post/read/68033/isomil-nu-dorong-perdamaian-dunia diakses pada 17 November 2016 jam 13.27 WIB.

http://khazanah.republika.co.id/berita/dunia-islam/islam-

nusantara/16/05/11/o6z3o3313-isomil-hasilkan-16-deklarasi-nu diakses pada 17 November 2016 jam 13.25 WIB

http://www.nu.or.id/post/read/68092/inilah-naskah-lengkap-deklarasi-nahdlatululama-kepada-dunia

http://www.moslemforall.com/peran-nu-dalam-mewarnai-dunia/ http://web.isanet.org/Web/Conferences/GSCIS\%20Singapore\%202015/Archive/8 0d19277-25a6-4fc4-8097-1c55d62c1744.pdf

http://web.isanet.org/Web/Conferences/GSCIS\%20Singapore\%202015/Archive/8 0d19277-25a6-4fc4-8097-1c55d62c1744.pdf https://www.bangsaonline.com/berita/918/inilah-sembilan-rekomendasikonferensi-ulama-internasional?browsefrom $=$ mobile 